\title{
69. We are what we read: reading identity of university students of English language teaching
}

\author{
Hasan Serkan KIRCA ${ }^{1}$ \\ Philip GLOVER ${ }^{2}$
}

APA: Kurca, H. S.; Glover, P. (2021) We are what we read: reading identity of university students of English language teaching. RumeliDE Dil ve Edebiyat Araşttrmaları Dergisi, (24), 1182-1194. DOI: 10.2900o/rumelide.997589.

\begin{abstract}
Reading plays an important role in learning and is a source of educational, social and life experiences. How learners see themselves as readers can be viewed as reading identity, and reading identity is likely to affect the development of knowledge and skills at all levels of education, including university level. This paper looks at the reading identity of 45 students of English Language Teaching (ELT) at a university in Turkey expressed through written reports, learner diaries and interview data that were collected while they were taking a course in English literature. Analysis shows how the students presented themselves in terms of what they read, how well they read and how they positioned themselves in relation to other readers, to different texts and to their own feelings about reading in their first and second languages. Three types of reading identity were found in the data: manifest state identity, where reading is an important part of the student's life, introjected state identity where reading is strongly associated with one aspect of the student's life as a professional English teacher and neutral state identity where reading is limited to being a tool for communicating meaning in certain situations. Findings have implications for curriculum content and methodology and provide insights into the role of reading in the students' educational lives.
\end{abstract}

Keywords: Reading identity, manifest, introjected and neutral identity, literature course, ELT

\section{Ne okuyorsak oyuz: İngiliz dili eğitimi öğrencilerinin okuma kimliği}

\section{$\ddot{\mathbf{O z}}$}

Okuma, öğrenmede önemli bir role sahiptir. Okuma eğitim ve sosyal hayattaki deneyimlerinde kaynağıdır. Okuma kimliği, öğrencilerin kendilerini okuyucu olarak nasıl gördükleri olarak ifade edilir. Okuma kimliği üniversite düzeyi de dâhil olmak üzere eğitimin tüm seviyelerinde bilgi ve becerilerin gelişimini etkileyebilmektedir. Bu çalışma, Türkiye’de bir üniversitede İngiliz Dili Eğitimi okuyan 45 öğrencinin raporları, günlükleri ve röportajları aracılığıyla okuma kimliklerini incelemektedir. Yapılan analizler; öğrencilerin ne okuduklarını, ne kadar iyi okuduklarını ve kendilerini diğer okuyuculara, farklı metinlere, birinci ve ikinci dillerinde kendi duygularına göre nasıl konumlandırdıklarını göstermektedir. Bu çalışma için toplanan verilerde Açı İfade Kimliğ $i$ (Manifest State Identity), Iç̧e Yansıtılmış Iffade Kimliği (Introjected State Identity), ve Tarafsız Iffade Kimliği (Neutral State Identity) olarak üç tür okuma kimliği tespit edilmiştir. Açı ifade kimliği, okumanın öğrencinin hayatında önemli bir yere sahip olduğu kimliktir. İçe yansıtılmış ifade

Doktora, Süleyman Demirel Üniversitesi, Sosyal Bilimler Enstitüsü, Batı Dilleri ve Edebiyatı (Isparta, Türkiye), teacherserkan@yandex.com, ORCID ID: o0oo-0002-4864-6463 [Araştırma makalesi, Makale kayıt tarihi: 31.08.2021kabul tarihi: 20.09.2021; DOI: 10.29000/rumelide.997589]

Dr., Süleyman Demirel Üniversitesi, Fen Edebiyat Fakültesi, Batı Dilleri ve Edebiyatı (Isparta, Türkiye), pgaglover@gmail.com, ORCID ID: 0000-0002-2375-3633

Adres | Address

RumeliDE Dil ve Edebiyat Araştırmalar Dergisi $\quad$ RumeliDE Journal of Language and Literature Studies

Osmanağa Mahallesi, Mürver Çiçeği Sokak, No:14/8 $\quad$ Osmanağa Mahallesi, Mürver Çiçeği Sokak, No:14/8

Kadıköy - ÍSTANBUL / TÜRKIYE 34714 Kadıköy - ISTANBUL / TURKEY 34714

e-posta: editor@rumelide.com e-mail: editor@rumelide.com,

tel: +90 505 7958124, +90 2167730616 phone: +90 505 7958124, +90 2167730616 
kimliğinde öğrenci okumayı profesyonel bir İngilizce öğretmeni olarak hayatının bir yönü ile güçlü bir şekilde ilişkilendirmektedir. Son olarak tarafsız ifade kimliğinde ise okuma belirli durumlarda anlamı aktarmak için kullanılan bir araçtır. Bulgular müfredat içeriği ve metodolojisi için çıkarımlara sahiptir ve okumanın öğrencilerin eğitim hayatlarındaki rolüne dair içgörüler sağladığını da ortaya çıkarmıştır.

Anahtar kelimeler: Okuma kimliği, açık, içe yansıtılmış, ve tarafsız kimlik, edebiyat dersi, İngiliz dili eğitimi

\section{Introduction}

Identity and learning share a number of common characteristics as they are social, changeable and multi-faceted. Language and reading play important roles in the construction of identity and in learning and the saying 'We are what we read' suggests that reading reflects who we are. How people talk about their reading reveals much about the identity that an individual wishes to present to others, and referring to what one reads, how one reads and what one gains from reading are ways of signaling one's attitudes and viewpoints. In education, reading is not just a skill and an important source of knowledge but is also a way to gain experience of the wider world and find out about different people, places, and behaviour. This paper uses insights from poststructuralism and sociocultural theory, emphasizing the social nature of identity, language and learning in order to look into how the members of one group of students present themselves as readers.

Identity relates to how people position themselves in society: how people understand their relationship to the world around them; how that relationship is constructed across time and space; and how people understand their possibilities for the future (Norton, 2000). Identities are constructed by individuals and influenced by a plethora of experiences over time, which include what learners read, write, and talk about throughout their lives. Identity changes over time, fluid and dynamic rather than fixed and both 'context-dependent and context-producing' (Norton \& Toohey, 2011, p. 419). Social identity (Tajfel, 1981) highlights the role of group membership and emotional attachment. A model for identity in relation to language use has been produced by Thomas and Osment (2018, pp. 1006-1007) as manifest, introjected and neutral states. In a manifest state 'the language is a strong part of an individual's broader identity' and is part of the way the individual 'thinks, feels and acts'. Introjected state identity reflects a situation where the language has 'not yet been fully internalised' but 'is a subjective feeling of partial association with only certain aspects of a particular language'. The third state in this model is neutral state identity, which 'is assumed when a language is purely a tool to convey meaning in specific situations', and where the language user 'does not have any sense of personal association with the language'. These kinds of identity are seen as important to learning and language learning because the changeable nature of identity offers ways of understanding and supporting how students learn.

Individuals can position themselves in society by talking about some aspect of their identity such as reading. Positioning is performed to a large extent through discourse and positioning is permitted and constrained by the various discourses that are available to that individual (Menard-Warwick, 2005). Poststructuralism provides theories that help to explain positioning (Norton, 1995), for example how social status is expressed by individuals through different discourses in literature and in conversations: 'social position, rank, and importance are reflected in utterances of everyday and business speech communication' (Bakhtin, 1986, p. 96). Consequently, how learners talk about their reading reflects the various aspects of their reading identity.

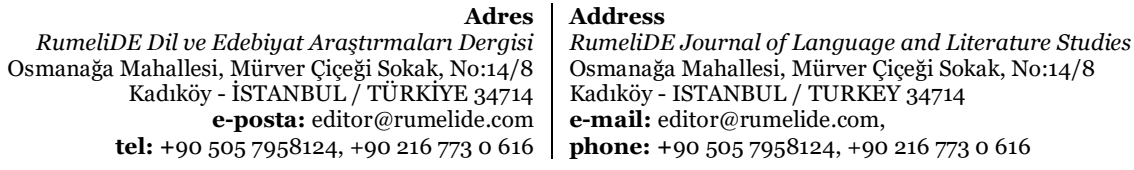


If experiences form identities, then reading contributes to identity in two ways as it is both an experience in itself and is formed by other experiences. Reading gives meaning to a text based on the reader's own experiences and previous knowledge (Rosenblatt, 1995), and readers bring with them all their experiences and emotions when they read a text so each reader will have a different experience with the text compared to their peers. Sharing these different experiences through interaction with the text and with classmates creates a community of readers (C. Thomas, 2000), and a reader's own reading identity is thus formed and strengthened (Francois, 2013). The contribution that interaction with classmates makes to learning is confirmed by sociocultural theory of cognitive development (Vygotsky, 1978).

Reading identity, or how readers position themselves as readers in relation to texts and to other readers, is an identity which is constructed and develops throughout education. Student reading identity can be defined as the manner in which students view themselves as readers inside and outside class in relation to the texts and to the other members of the class (Bonafide, 2011). Reading identity is formed not only inside the reader but with members of a group, for instance a class of students. Reading identity comprises skills, as well as what is read, what kind of text is read, how it is read, what is understood from the given text and how learners actualize what they have read. Studies of reading identity have been largely focused on secondary school contexts, especially in North America, in research that aimed to understand students' reading and promote literacy. In a first language context, the school shapes students' identities by 'accepting, promoting, rejecting and transforming the senses of self and social belonging that children bring to and take from this institutional encounter' (Collins, 2005, p. 106). Students' comprehension strategies change based on their identities as readers and their reading levels. High-performing readers employ comprehension strategies to deepen their knowledge of content and to support their interpretations of text and use the most helpful strategies to solve their specific comprehension problems. The students who identified as average or low-performing readers employed only one or two favorite strategies to get the success. Miller (2013) investigated issues of motivation and identity from the perspective of fourth grade students as these students experienced the workshop model of instruction for the first time and showed that self-selected books made the students more motivated. In addition, self-selected books develop the identity of the students. A study of the construction of reading identity by struggling middle school readers investigated reading identity as self-concepts concerning the students' views of themselves as readers and tried to identify in-school factors which impact student reading identities, including interactions with remedial and classroom teachers, as well as out-of-school factors such as family literacy (Bonafide, 2011). What happens inside and outside the classroom regarding reading is also likely to be important in a university L2 setting.

The reading identity of students has not been investigated per se in a Turkish university context before, but research has been carried out into ELT students' views of reading literature in the context of English literature courses that are part of the curriculum. Literature courses in the ELT programme have been 'a matter of fervent discussion' (Arikan, 2005, p. 27), and studies have focused on the content of literature courses and their relevance to the needs of future English teachers (Gündüz, 2005; Kaya, 2018; Vural, 2013). Some studies looked at the role of literature as part of teaching English as a foreign language (Tevdovska, 2016). The reasons for having literature courses in the ELT curriculum are that reading literature can support language learning, provide cultural knowledge a broader vocabulary, increase general knowledge and encourages higher level thinking skills (Yllmaz, 2019). Most previous studies found that students have a positive view of reading and were based on questionnaires or Likertscale type statements accompanied by interviews (Çıraklı \& Kılıçkaya, 2011) and some compared student responses at the beginning and end of the literature course (Kaşloğlu and Ersin, 2018). Some studies collected data about the reading that students perform (Tehan, Doğan, \& İnan, 2015; Zorba, 2013).

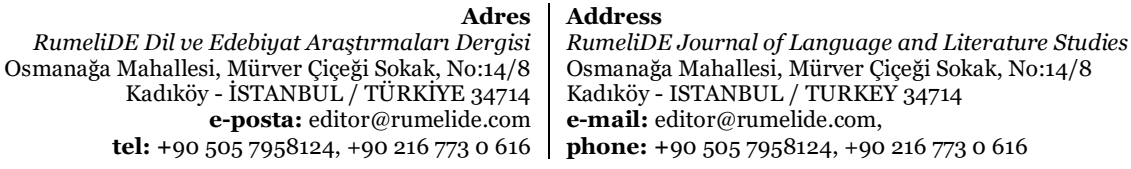


These previous studies were primarily focused on the content of the courses and how they were taught. The concept of reading identity allows university students' reading to be placed in a broader context.

\section{The study}

The study described in this paper investigated the reading identity of a group of students at a university in Turkey. The students were asked about how and why they read, about the benefits of reading and about their aims and feelings concerning reading. The study was carried out while the students were taking a course which taught about literary movements and writers from English literature. This was a mixed methods study where the data elicited from the students were analysed quantitatively by counting the proportions of students giving different answers, but the main method was qualitative as the content of the students' responses were carefully compared, grouped and categorised.

\subsection{Context}

The participants in the study were ELT students at a state university in Turkey. They were composed of 45 respondents, 18 male and 27 female, with an average age of 20, all of whom completed written reports about their reading at the start and end of the course. Nine of the students were selected to provide data for closer study and they wrote weekly learner diaries and were interviewed by the researcher three times. These students were chosen on the basis of 'purposive sampling' (Cohen, Manion, \& Morrison, 2000, p. 103), where the researcher chose students on the basis of their first reports to represent three groups: successful readers, partly successful readers and unsuccessful readers. The use of multiple methods of data collection aimed to provide a variety of opportunities for the students to express their opinions about their reading. The analysed data consisted of nearly 50,000 words, 9439 words in the first reports, 10550 words in the second reports, 11,557 words in the learner diaries and 15526 words in the interviews. Appropriate informed consent was obtained from the students at the time of data collection.

Short reports of 250-350 words have been used by researchers to investigate students' thinking because they provide more information than a questionnaire or Likert scale statements but are not too timeconsuming for the students to write (Wei Su 2020). Students' reports are specific forms of writing that are organized around briefly identifying and examining students' viewpoints on a topic. Narrative frames adopt a similar approach (Barkhuizen, 2008) as stories of experience lived and told (Connelly, 1990; Pavlenko, 2002). By eliciting more information about what and why the students read and by analysing the responses carefully the validity of the study is enhanced. Learner diaries are designed to collect personal and deep information about the students' reading. Learner diaries as first-person observations of experiences that are recorded over a period of time. The students were asked to write about what they read, how well they read, how they felt about their reading, how they felt about the lessons and how well they thought their classmates read and responded to the lessons.

People present their identity using available discourses, which are a way of communicating for the participants, a 'sharing of knowledge or experience' (Schiffrin, 1994, pp. 388-389). The main method of analysis of the data was qualitative discourse analysis, where the researcher aimed to conduct a careful, detailed analysis of empirical data because 'discourse analysis requires a careful reading and interpretation of textual material' (Mason, 1996). The study aimed to answer three research questions relating to what the students read, how the students read, and the which type of reading identity they

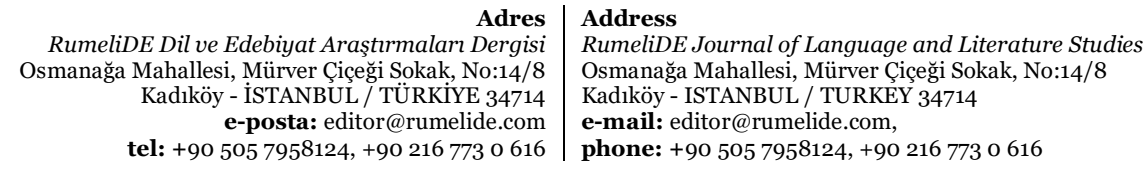


present. The study considers not only reading literature but also all kinds of reading as part of reading identity in the first and second languages. Research questions were:

1. What do these students read?

2. How do the students read?

3. What reading identity do the students present?

Analysis of reading identity types adapted a three state framework which was originally proposed by Thomas and Osment (2018) for analysing identity and language use. This framework has three states of identity: manifest, introjected and neutral (N. Thomas \& Osment, 2018). For the purposes of this study manifest state reading identity is when reading is felt strongly by an individual to be very much part of their identity in a wide variety of ways. Introjected state reading identity is when there is partial association of reading with some aspects of a group such as when reading is part of an individual's broader identity but has some limits or boundaries. The third type of identity is neutral state reading identity, when reading is just a way of communicating meaning in certain situations and the individual does not feel a personal association with reading and there are no strong connections with the other members of the reading group because reading is purely transactional.

\section{Analysis}

The reports submitted by the 45 students in the study were analysed and produced results showing what the students read, the benefits they perceived and how well they read. In addition learner diary and interview data from nine of the students were analysed in order to provide a finer picture of reading identity by adding more details about how these students saw themselves in relation to their classmates, how the students responded to different texts and activities during the course, and how they felt about reading.

In the reports the students responded to ten questions about what they read in Turkish and English, how well they read, their feelings about reading literature, their motivation for reading literature and their expectations regarding the literature course and future use of English literature. There were eight prompts for the interview and learner diaries which asked questions about what the student had done during the course, how they felt about reading English literature, how well they read and how they perceived classmates' reactions to English literature. The data were coded according to the content of what the students said and wrote about reading which produced 25 codes relating to experiences, preferences, motivation, feelings and attitudes. These codes were then linked to the research questions. Five codes were connected to the first research question (what the students read): preferences in Turkish, preferences in English, reading experience, material read in Turkish and material read in English. Eight codes were connected to the second research question (how the students read), and these codes were based on their success, skills and abilities as readers. Twelve codes were connected to the third research question (the students' self-positioning as readers): how the students positioned themselves with regard to other members of the group, with regard to different texts and activities and how they felt about reading.

\subsection{What the students read}

In the reports that they wrote at the start and end of the literature course the students identified three types of text that they read: literary texts, ELT-related texts and news and current affairs media. Some

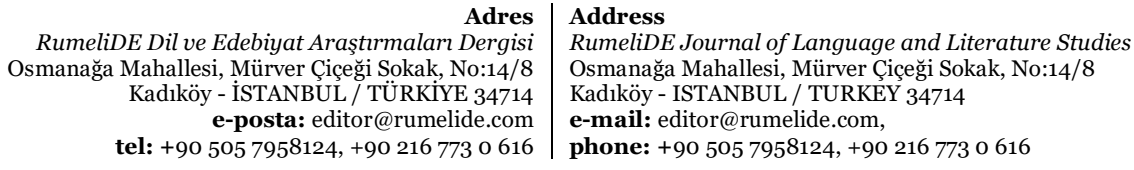


students described a wide variety and a large number of texts, most referred to some texts and text types and a small number referred to few or no texts. The students' responses indicate that most wanted to be seen as people who did some or a considerable amount of reading, and in most cases the reading that they referred to was literature. There were few differences between the categories of reading reported in the first and second reports.

The students' reading in Turkish and English in the first reports are presented in Table 1 below. All the students reported reading some kind of text in Turkish, and all but one in English. Literature is the most common text referred to, which is not surprising as the questions were asked in the context of a literature course. A total of 41 students said that they read literature in Turkish, and of the four who did not refer to reading literature, three students referred to only ELT texts or ELT texts and news media and one stated that they only read news media. For reading in English, 27 said that they read literature in English, which means that 18 , or more than one third of the students, did not refer to reading literature in English. One student did not refer to reading anything in English, and of the remaining 17 students, eight referred to ELT texts and nine referred to only news media. One in five of the students did not refer to reading literature or ELT texts. These students' reports show that reading was widely practiced by members of the group, but reading in English was practised less.

Table 1. Reading in Turkish and English in the First Reports

\begin{tabular}{lll}
\hline & Reading in Turkish n=45 & Reading in English n=45 \\
All three, literature, news media, ELT & 2 & 1 \\
Two, literature and ELT & 1 & 6 \\
Two, literature and news media & 13 & 4 \\
Two, news media and ELT & 1 & 6 \\
Only Literature & 25 & 16 \\
Only news media & 1 & 9 \\
Only ELT & 2 & 2 \\
No reading mentioned & 0 & 1 \\
\hline
\end{tabular}

There are many similarities between the first and second reports (see Table 2) in terms of what the students read. In the second reports all the students reported reading some kind of text in both Turkish and in English, and 38 students said that they read literature in Turkish. Of the students who did not refer to reading literature in Turkish, three students referred to ELT texts and four referred to reading news media. For reading in English, 28 said that they read literature in English. Of those who did not refer to reading literature in English, ten referred to reading only ELT texts or ELT texts and news media, and six referred only to news media. The second reports again showed that reading was widely practiced by members of the group, with reading in English still being practised less.

Table 2. Reading in Turkish and English in the Second Reports

\begin{tabular}{|c|c|c|c|}
\hline & \multicolumn{2}{|c|}{ Reading Turkish $n=45$} & Reading English $n=45$ \\
\hline All three, literature, news media, ELT & \multicolumn{2}{|l|}{3} & 2 \\
\hline Two, literature and ELT & \multicolumn{2}{|l|}{2} & 6 \\
\hline Two, literature and news media & \multicolumn{2}{|l|}{11} & 3 \\
\hline Two, news media and ELT & \multicolumn{2}{|l|}{$\mathrm{o}$} & 5 \\
\hline Only Literature & \multicolumn{2}{|l|}{22} & 17 \\
\hline \multicolumn{2}{|c|}{$\begin{array}{r}\text { RumeliDE Dil ve Edebiyat Arașttrmaları Dergisi } \\
\text { Osmanağa Mahallesi, Mürver Ciçeği Sokak, No:14/8 } \\
\text { Kadıöy - İSTANBUL / TÜRKIYE } 34714 \\
\text { e-posta: editor@rumelide.com } \\
\text { tel: }+905057958124,+90216773 \text { o } 616\end{array}$} & $\begin{array}{l}\text { Address } \\
\text { RumeliDE Journal of } \\
\text { Osmanağa Mahallesi, } 1 \\
\text { Kadıköy - ISTANBUL } \\
\text { e-mail: editor@rumel } \\
\text { phone: +90 } 5057958\end{array}$ & $\begin{array}{l}\text { zge and Literature Studies } \\
\text { CCiçeği Sokak, No:14/8 } \\
\text { EYY } 34714 \\
\text { n, } \\
90216773 \text { o } 616\end{array}$ \\
\hline
\end{tabular}




\begin{tabular}{lll}
\hline Only news media & 4 & 6 \\
Only ELT & 3 & 5 \\
No reading mentioned & $\mathrm{o}$ & $\mathrm{o}$ \\
\hline
\end{tabular}

Results of analysing the reports show that nearly all members of this group of students read a variety of texts, but not all the students read texts in both Turkish and English. It is interesting to note that while all but one of the students said that they read in Turkish, a substantial minority, more than a third, did not extend their reading of literature and ELT to English. This discrepancy will be investigated in the next part of the analysis which looks at how the students read, and in the final part of the analysis on how the students positioned themselves as readers.

\subsection{How the students read}

The students' responses relating to how they read describe the students' success, effectiveness, and abilities for reading. Some students saw themselves as successful, effective and highly competent readers, a larger number saw themselves as partly successful, competent readers but with some doubts about their reading abilities in English, and a few said that they were unsuccessful or reluctant readers. More students said that they were successful readers in the second reports and fewer said that they were partly or unsuccessful. Quotations from what the students wrote are identified by an anonymized participant number, then a data code, R1 for the first report, R2 for the second report, D for the learner diary and I1 for the first interview, I2 for the second interview and I3 for the third. Thus P36R2 stands for participant 36 in the second report.

In the reports the students were asked to state how well they thought that they read. The researcher categorised the responses as indicating successful readers, partly successful readers and unsuccessful readers. The responses in each category are shown in Table 3. Students felt more confident about their abilities in Turkish and less confident about their abilities to read in English.

Table 3. How students see themselves as readers in first and second reports.

\begin{tabular}{lll}
\hline Type & First Report $(\mathbf{n = 4 5})$ & Second Report $(\mathbf{n}=\mathbf{4 5})$ \\
Successful & 15 & 28 \\
Partly successful & 28 & 17 \\
Unsuccessful & 2 & 0 \\
\hline
\end{tabular}

Some students believed that they were good readers and were confident in their ability to read all kinds of text including literature in both Turkish and English. Students who said that they were successful readers referred to their experience of reading well and their pleasure when reading literature. Some showed great enthusiasm: I love reading both in Turkish and in English and I am a good reader because I find the English literature interesting and amazing and it makes me want to read more without getting bored or fed up (P36R2). Respondents categorized as successful readers had an inclination to read any kind of material in English and Turkish, for example: I can read anything written in modern English. This is a result of reading a lot in English (P34R2). Success was expressed in terms of comprehension: My ability is good I think because I can understand what is written in a text immediately if it is not too hard or advanced and it makes me a good reader I think (P36R2).

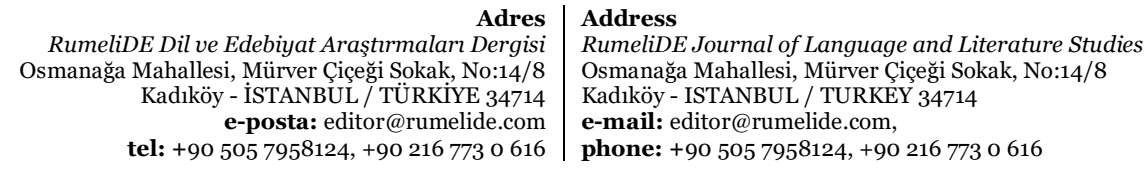


Other students said that they could read fairly successfully but with some reservations because they were less sure about their reading abilities in English. Those who were unsure about their reading had concerns about their comprehension abilities. Concerns about reading ability were often connected to lack of vocabulary knowledge which led to reading slowly and taking time to look words up in a dictionary. Several students expressed a preference for easily accessible texts in English, for example: In English, I generally like reading news and novels that are simple to understand because they help me to improve my vocabulary (P44R1). News media materials such as newspapers and magazines, were read by 16 of the students in Turkish, and 15 in English, for example: I read a newspaper in English because I can understand it easily and it improves my vocabulary skill ( $\left.\mathrm{P}_{5} \mathrm{R} 1\right)$. Some students were rather in awe of reading literature, seeing the reading of literature as different from other types of reading: when I hear this word literature I am getting nervous. I think literature is terrifiying and boring. When anybody says literature, immediately I think that there are lots of things I have to learn by heart... reading literature is difficult and I don't prefer reading literature (P18R1). For others the topic of the text was important for reading: I can read and understand the text which is appropriate for me, that means, I am able to understand the texts that appeal to me (P23R2). The more negative responses to the study of literature tended to occur in the first reports but much less in the second reports.

Lack of vocabulary was also seen as a problem for reading literature: I prefer to read in Turkish. I think my vocabulary knowledge is not enough to read literature ( $\mathrm{P}_{32 \mathrm{R} 2) .}$. Comprehension, reading ability and interest in the text were connected for some students: Actually my reading ability is not enough. when I read something, I can't exactly understand. If the subject appeals to me, I can understand the words I don't know (P18R2). Lack of reading experience was also seen as a problem to be solved: It is not good as I wish. Because I haven't read much so far. But I want to improve it as soon as I can. To succeed that, I have started to read in English more (P31R1). Another student commented: I am a bit lacking of this skill actually because I've not read in English. I think I am developing myself day by day by reading (P11R1).

A small number of students wrote that they read little or not at all and only read if required to do so for exam grades. Some of these students had little experience of reading, saw reading as an obligation, tended to read in Turkish but not in English, knew the importance of reading but lacked the desire to read, or felt good about reading but did not spend time on reading, and knew the importance of reading for their profession but lacked confidence about reading.

The second reports show that more students saw themselves as successful after the course. A student read in English for exams and for language study at the start of the course:

\begin{abstract}
I supposed that it was 2 years ago when I read the first English novels. To be honest I read these books to only pass exam. but after I think that reading English books contributed to my English ability. When you read English books you came across different structures of sentence. So you are realizing how you can set up sentence which you want to say but you couldn't (P13R1).
\end{abstract}

By the end of the course the same student had become more of a committed reader in English: Firstly, I start to read this book for only homework. after I read 20-30 pages I couldn't leave the book. I finished it in short time (P13R2).

At the end of the course another student was comfortable with reading both in Turkish and English:

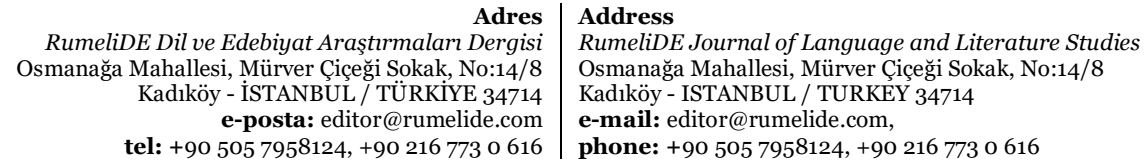

RumeliDE Dil ve Edebiyat Araşttrmaları Dergis tel: +90 505 7958124, +90 2167730616 
I read magazines about literature, if I am to give example I can say Kafka okur. I believe that there does not have to be any reason to read, I read because it makes me feel alive, it makes me feel out of this world for a little while more. It feeds my soul, it brings out my inner personality. In Turkish I usually prefer to read old novels from best authors like Oğuz Atay, Sabahattin Ali etc. I think they just write my thoughts. I read novels in English, I love reading quotes of remarkable peoples. Because when they are translated in to Turkish it does not give you the same feelings. That is why I prefer to read them in English. I also prefer to read poems in English. I also read daily news in English to learn what is going on all around the world (P16R2).

A number of students reports show a progression from being partly successful readers at the start, showing some reticence about reading in English, to seeing themselves as successful readers. The quantity of reading did not seem to change during the course, as shown in Table 2, but the quality of reading done seems to have changed.

\subsection{Reading identity presented by the students}

The codes that related to reading identity were grouped according to the framework of manifest, introjected or neutral state identities. Student responses that showed strong personal or emotional commitment to reading were grouped as presenting a manifest state reading identity. Those responses that referred to reading as being important for a specific reason, usually out of professional commitment as future teachers were grouped in the category of introjected sate identity. Responses that referred to a desire for quick and easy reading experiences, contained negative viewpoints about reading or which saw studying just for grades as the reason to read were grouped as neutral state identity. The students presented their identities in three ways: by talking about their feelings about reading, by giving their reasons for reading and by talking about themselves in relation to other students.

Responses that were grouped with a manifest state reading identity presented a strong personal commitment to reading that was often emotional and based on an appreciation of the benefits of reading. Reading literature, perhaps, is most of my life. I learn many things from books... When I was reading literature I feel like that a power keeps control of my heart (P6R1). There are comments showing a love of literature and reading, for example: Books are an ocean and I am a drop in it. I lose myself while reading. I can't think of a world without books and literature. It would be darkness (P12R2). These comments indicate students who wish to present themselves as avid readers: I always read a book before I sleep there is always a book in my bed I try to read a few pages before I sleep (P10I2).

Similarly: I read 48 books in a year. That's not, that's not a bad number I think. But it's not quite good I believe. I should work on it. I don't think I'm not a good reader, I'm not a bad reader also. The genre doesn't matter for me, I like every kind of books (P10I1).

Other comments show how the student connects with reading, for example:

Outside the classroom, I came across a poem called "Still I Rise" by Maya Angelou. It was about women who are strong despite everything. I liked it because it reminded me some moments from my life. Also I realized that I like reading poems. This week I started reading "Kamelyalı Kadın" by Alexandra Dumas. I've almost finished half of the book. I enjoy reading classics because those books can change your view of life and the events seem interesting as they are related to past (P1OI2).

Students with an introjected state reading identity see reading as part of a professional commitment to teaching because reading is important for teachers as a source of knowledge about teaching. Comments show that students see knowledge of English literature as a requirement for English teachers: As English literature is one of the basic things in ELT, I feel it a bit necessary (P34D). Knowledge of the literary canon is seen as important: there are some main pieces of English Literature I think if I want to be a

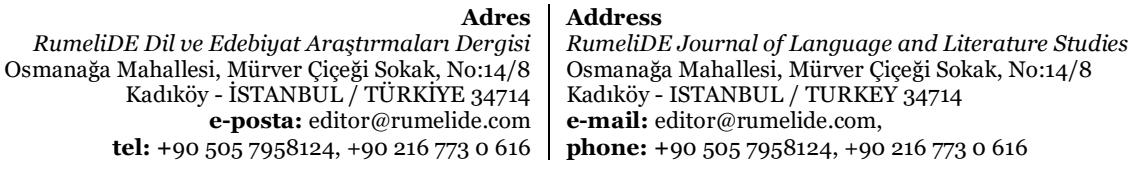


teacher, I should know these pieces (P10I1). Literature is seen as something beneficial for sharing with future students: When, when I finish the university I want to be a good teacher and I want my students to like literature also (P10I1). Comments relating to the students' future teaching career show that the commitment to teaching is stronger than their commitment to reading.

Comments that belong to the category of neutral state reading identity show some reluctant readers who say that they only read when they are forced to by course or exam requirements. Some students see reading as desirable but time-consuming as they feel under pressure to complete work for other courses, although motivation might come from exams. Far fewer students gave negative comments at the end of the course compared with the start. One or two students have a negative attitude to reading, especially to reading literature in English. Their comments include: I think that literature is boring, so I feel that I have to read it when I read it. I don't understand it and I just read it because somebody, for example my teacher, forces me to read it (P22R2). Another comment states an aversion to literature in itself: I don't feel enjoyable in reading literature, it doesn't matter whether Turkish or English literature. Because I read or someone read literature books in class, I feel bored and these kinds of books don't look attractive for me (P17R1). Another comment states: To be honest if my teacher says to us "exam will be related to these books" I can be motivated to read English literature. Actually, I'm not eager to read literature but I have to, of course, it's a lesson ( $\mathrm{P} 7 \mathrm{R} 1)$.

In the data there are two types of comment that referred to other students: comments about other students' responses to the course and comments about activities. Most comments about other students' responses showed that most see the group as not being very interested in reading literature. A few of these comments fall into the neutral state identity group, showing an aversion to reading literature, and a perception that others in the class are more successful than they are: But my classmates generally I think they feel more enjoyable in the literature lesson in class because they are more interested in lesson than me (P11I2). More comments are in the introjected state group. Although they see reading for the group as important for developing knowledge about teaching, language skills and experience of the world, they are held back by the various difficulties presented by reading. Some comments refer to other class members as 'they', for example: My classmates, I can see them getting bored with this literature... this is something that they don't know, this is something strange for them (P16I1). Some comment that other students' lack of interest affects their level of participation in the course: $M y$ classmates seem to be not interested in English Literature ... and I don't think they are so interested in English Literature and they don't they are not so involved in this course (P29I1). Other comments speak as a member of the group using 'we': I feel the same thing about my friends actually because we most of us don't have any special interest in English Literature just it is a lesson sometimes we should pass these exams. We think like that (P29I3).

There are comments that identify some students in the class as enthusiastic readers:

I realized that there some ... friends who are eager to learn about English Literature, they are not bored I think. Because I realize that when I ask questions or when they are expressing their ideas about the topic, they are eager to learn or they, they already know something about the subject. So I think they like reading English Literature, they are enjoying (P1OR1).

Other comments suggest beneficial effects of the course: some of my friends they brought me $a$, $a$ magazine that they had been making on their own like, three friends they were writing some poems and stuff like that, about their own thinking, own ideas. I think it's a really good thing (P16I2).

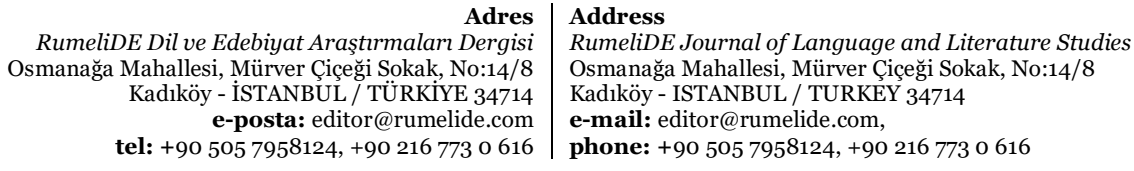


A number of comments referred to other students' responses in relation to weekly presentation activities given by the students in class. All comments about these were positive and enthusiastic, indicating the contribution of social aspects of learning to reading. Some students found the presentations entertaining: Anyways we have discussed about Robinson Crusoe. Our friends also made a movie about it and it was nice to watch it. I like it when people put some effort on their work and you can clearly see it (P16D). working on aspects of literature together with classmates was seen as more productive than study at home: As I sald before this week I had fun and like what we did in the lesson. If I read the plays or poems at home it would not be so effective and permanent (P29D). Another comment was: Our friends made presentations which were so funny. Because we act in our plays that makes them humorous. I really like this lesson (P38D). these activities were also seen as motivating: as we started shooting videos it became more enjoyable I think. It is you know the visuals are, are more memorable and so I like watching videos of our friends. It makes me ... want to read more English Literature. I like it (P10I3). The positive effect of group and presentation work reflects Vygotsky's sociocultural theory.

The way the students refer to their reading brings out the changeable, social and multi-faceted nature of reading identity. Reading identity is changeable as can be seen in the differences between the students' views of reading in the first and final reports. These students' reading identity is social as their positive response to the group preparation activities for class show. Reading identity is multi-faceted as the students present their relationship to reading and the world in different ways: some have a strong and close relationship with reading, others have more of a professional relationship and others seem to want to limit the role of reading in their lives.

\section{Conclusions}

The focus on reading identity in this study presents a picture of students who see reading in different ways and position themselves as different types of readers. Some position themselves as avid readers who have a strong personal commitment to reading because reading provides them with emotional, academic and social learning. Others position themselves as serious readers who are mainly focused on reading as a source of knowledge and information about teaching. A third, much smaller group, reads reluctantly, does not enjoy reading and sees examinations and course requirements as the reason to read. The reading identity that the students present is often fluid and dynamic, changing before, during and after the course. Influences on the students' perceptions of reading are related to social learning experiences gained during the course.

The students' comments about reading illustrate the extent to which reading is more than just a skill that can be applied in different ways by different types of readers. Reading identity is about how readers relate to the world and connects with ideas from poststructuralism and sociocultural theory. The relationship that students construct with the world and with reading is complex, as reading identity both forms the students' view of the world and provides experiences that affect how the students view their wider learning opportunities.

The main inhibiting factors regarding reading for some students are the perceived difficulty of reading in English, the second language, and for some the perception that reading literature can be 'boring'. It can be seen that after participating in the course and gaining experience of reading and English literature many members of the group became more confident about reading and to feel more positive. The social

\footnotetext{
Adres | Address

RumeliDE Dil ve Edebiyat Araştırmaları Dergisi $\quad$ RumeliDE Journal of Language and Literature Studies Osmanağa Mahallesi, Mürver Çiçeği Sokak, No:14/8 Osmanağa Mahallesi, Mürver Çiçeği Sokak, No:14/8 Kadıköy - ÍSTANBUL / TÜRKIYE 34714 Kadıköy - ISTANBUL / TURKEY 34714 e-posta: editor@rumelide.com e-mail: editor@rumelide.com, tel: +90 505 7958124, +90 2167730616 phone: +90 505 7958124, +90 2167730616
} 
learning activities involving group presentations that were part of the course seem to have contributed to the students' confidence and outlook.

\section{References}

Arikan, A. (2005). An Evaluation of Literature Curriculum in H.U. English Language Teaching Department. Online Submission, 29.

Bakhtin, M. M. (1986). Speech Genres and Other Late Essays. Austin: University of Texas.

Barkhuizen, G., \& Wette, R. (2008). Narrative frames for investigating the experiences of language teachers. System, 36, 372-387.

Bonafide, A. M. A. (2011). The Construction of Reading Identity in Struggling Middle School Readers State University of New York, New York, USA.

Cohen, L., Manion, L., \& Morrison, K. (2000). Research Methods in Education. London: Routledge.

Collins, J., \& Blot, R. K. . (2005). Literacy and literacies. Cambridge: CUP.

Connelly, F. M., \& Clandinin, D. J. (1990). Stories of experience and narrative inquiry. Educational Researcher, 19(5), 2-14.

Çırakll, M. Z., \& Kılıçkaya, F. (2011). Literature Courses in EFL Curriculum: Pre-Service Language Teachers' Perceptions. Pegem Eğitim ve Öğretim Dergisi, 1(3).

Francois, C. (2013). Reading is about relating: Urban youths give voice to the possibilities for school literacy. Journal of Adolescent \& Adult Literacy, 57(2), 141-149. doi:10.1002/JAAL.218

Gündüz, N. (2005). A Suggested Syllabus for the Course Introduction to British Literature at ELT Departments.

Kaya, S. Ü. (2018). Integration of Literature in ELT Classes: A Survey of the Attitudes of ELT Students towards the Study of Literature. Başkent University JournaI of Education, 5(1), 51-60.

Kaşlığlu, Ö., \& Ersin, P. (2018). Pre-service teachers' beliefs about literature integration in English language teaching classrooms. Journal of Language and Linguistic Studies, 14(3), 213-232

Mason, J. (1996). Qualitative researching. London: Sage.

Menard-Warwick, J. (2005). Both a fiction and an existential fact: Theorizing identity in second language acquisition and literacy studies. Linguistics and Education, 16(3), 253-274. doi:https://doi.org/10.1016/j.linged.2006.02.001

Miller, L. A. (2013). Developıng Reading Identitıes: Understanding Issues Of Motivation Within The Reading Workshop

Norton, B. (1995). Social Identity, Investment, and Language Learning*. TESOL Quarterly, 29(1), 9-31. doi:10.2307/3587803

Norton, B. (2000). Identity and language learning: Gender, ethnicity and educational change. Harlow, England: Longman/Pearson Education Limited.

Norton, B., \& Toohey, K. (2011). Identity, language learning, and social change. Language Teaching, 44(4), 412-446. doi:Doi: 10.1017/s0261444811000309

Pavlenko, A. (2002). Bilingualism and Emotions. Multilingua - Journal of Cross-Cultural and Interlanguage Communication.

Rosenblatt, L. M. (1995). Literature as Exploration (5 th edition)

Schiffrin, D. (1994). Approaches to Discourse. Oxford: Blackwell.

$\mathrm{Su}, \mathrm{W}$. (2020). Exploring how rubric training influences students' assessment and awareness of interpreting. Language Awareness, 29(2), 178-196. https://doi.org/10.1080/09658416.2020. 1743713

Tajfel, H. (1981). Human Groups and Social Categories. Cambridge: CUP.

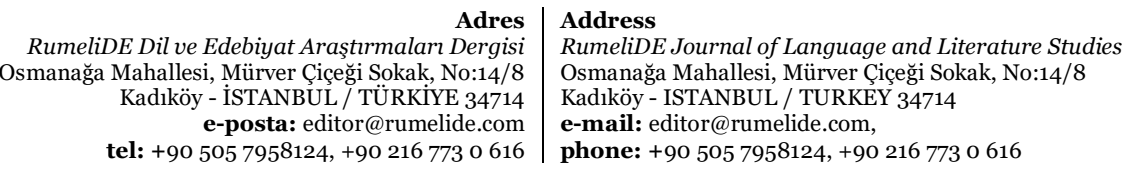


Tehan, P., Doğan, Y., \& İnan, B. (2015). The Place of Literature in an English Language Teaching Program: What Do Students Think About It? The Reading Matrix: An International Online Journal, 15(2).

Tevdovska, E. S. (2016). Literature in ELT Setting: Students' Attitudes and Preferences towards Literary Texts. Procedia - Social and Behavioral Sciences, 232, 161-169. doi:10.1016/j.sbspro.2016.10.041

Thomas, C. (2000). From engagement to celebration: A framework for passionate reading. Voices From the Middle, 8(2), 16-25.

Thomas, N., \& Osment, C. (2018). Building on Dewaele's (2018) L1 versus LX Dichotomy: The Language-Usage-Identity State Model. Applied Linguistics. doi:10.1093/applin/amzo10

Vural, H. (2013). Use of Literature to Enhance Motivation in ELT Classes. Mevlana International Journal of Education, 3(4), 15-23. doi:10.13054/mije.13.44.3.4

Vygotsky, L. S. (1978). Mind in society: the development of higher psychological processes. Cambridge: Harvard University Press.

Yılmaz, C. (2019). Using literature in the language classroom: Voices of pre-service EFL teachers. In H. Arslan \& G. Gianturco (Eds.), Contemporary Approaches in Social Science Researches (pp. 3541). Bialystock: IASSR.

Zorba, M. G. (2013). Prospective English language teachers' views on literature-oriented courses at Akdeniz University's Elt department. Procedia- Social and Behavioral Sciences, 70, 1911-1918. doi:doi: 10.1016/j.sbspro.2013.01.269

RumeliDE Dil ve Edebiyat Araştırmaları Dergisi Osmanağa Mahallesi, Mürver Çiçeği Sokak, No:14/8 Kadıköy - ISTANBUL / TÜRKIYE 34714 e-posta: editor@rumelide.com tel: +90 $5057958124,+902167730616$
Address

RumeliDE Journal of Language and Literature Studies Osmanağa Mahallesi, Mürver Çiçeği Sokak, No:14/8

Kadıköy - ISTANBUL / TURKEY 34714

e-mail: editor@rumelide.com,

phone: +90 5057958124, +90 2167730616 